\title{
Conventional Politics for Unconventional Drilling? Lessons from Pennsylvania's Early Move into Fracking Policy Development
}

\author{
Barry G. Rabe \\ Gerald R. Ford School of Public Policy, University of Michigan, Ann Arbor, Michigan, \\ $U S A$ \\ Christopher Borick \\ Political Science, Muhlenberg College, Allentown, Pennsylvania, USA
}

\begin{abstract}
The emergence of hydraulic fracturing techniques is generating a dramatic expansion of the development of domestic natural gas resources in the United States and abroad. Fracking also poses a series of environmental protection challenges that cut across traditional medium and program boundaries. Formal constraints on federal government engagement thus far devolve considerable latitude to individual states for policy development. This provides an important test of whether recent scholarly emphasis on highly innovative state environmental and energy policies can be extended to this burgeoning area. Pennsylvania has moved to the epicenter of the fracking revolution, reflecting its vast Marcellus Shale resource and far-reaching 2012 legislation. This article examines the Pennsylvania case and notes that the state's emerging policy appears designed to maximize resource extraction while downplaying environmental considerations. The case analysis generates questions as to whether this experience constitutes an influential state early mover that is likely to diffuse widely or is instead an aberration in a rapidly diversifying state policy development process.
\end{abstract}

KEY WORDS: energy policy, environmental policy, shale gas policy, hydraulic fracturing, fracking, state energy policy

0

ne of the most widely noted developments in American public policy in recent decades has been expanding state government capacity to forge innovative approaches in the absence of clear guidance from the federal government. This has been evident in environmental protection, where the continued inability of respective Congresses and presidents to address pressing environmental challenges has been supplanted by far-reaching environmental policy engagement from statehouses. Much of this work has been heralded by a range of scholars as highly innovative, making considerable use of such tools as regulatory integration across medium boundaries; promoting sustainability goals and preventive strategies wherever possible; and utilizing a range of integrative, market-based, and information disclosure tools (Dernbach, 2012; Fiorino, 2006; Mazmanian \& Kraft, 2009; Selin \& VanDeveer, 2009).

It has become, in fact, increasingly common to anticipate state "races-to-the-top" that emphasize environmental protection as a primary state policy goal, both to protect public health and to lure economic development sensitive to "quality-of-life" indicators (Rabe, 2013). Indeed, such races have often been triggered by so-called "first movers" or "early movers," states that attempt to set the standard for others by early actions that are dramatic and innovative. Such patterns have been evident in recent decades in numerous areas of environmental protection, including climate change mitigation, air and water regulatory integration, pollution prevention, open space conservation, and waste reduction, among many others. Under certain 
circumstances, it may indeed be possible for neighboring jurisdictions to join common cause, establishing comparable policies that benefit an entire region or ecosystem (Craik, VanNijnatten, \& Studer, 2013).

This optimistic pattern varies considerably from earlier depictions of American environmental federalism, which presumed that the federal government needed to take an active role in national environmental regulation, given the presumption that states would "race to the bottom." Under such a scenario, states would place such a premium on short-term economic development opportunities that they would routinely downplay environmental protection concerns. Entire state policy processes would be established that largely insulated established and emerging industries from environmental challenges, with states reluctant to take any unilateral environmental policy steps that might threaten their economic well-being by a shift of investment toward friendlier jurisdictions (Peterson, 1995). Such an analysis commonly was applied to issues that involved potential extraction of energy or other natural resources. In the former case, a dominant role was thought to be assumed by "powerful state-level subgovernments consisting of trade associations and industry officials (including pipeline companies as well as firms involved in exploration or production activities), state legislators, and regulatory agencies that frequently placed more emphasis on the promotional side of the energy business than on safety or environmental issues" (Davis, 2012, p. 178).

However, the emergence of a vast new energy source beneath the surfaces of more than half of the American states poses a critical test of how far they are prepared to pursue rigorous and innovative environmental protection in concert with resource development. Energy analyst Daniel Yergin has described shale gas as "the most significant innovation in energy so far since the start of the 21st century," one with capacity to generate substantial localized economic benefits through extraction (Yergin, 2011, pp. 329-30). This new energy source is not a renewable resource but rather the most environmentally benign form of fossil fuel in terms of greenhouse gas emissions and conventional air contaminants. Shale gas extraction is increasingly raising a sprawling range of environmental concerns that involve every environmental medium (air, land, and water) while also holding the prospect of substantial economic development opportunities. In turn, all existing federal legislation with potential application is statutorily constrained from addressing this energy source amid continuing federal policy-making inertia, thereby devolving most core governance decisions to states and localities. So do states race to the top or bottom in terms of environmental protection commitment or seek some common middle ground with neighbors? Under conventional thinking, we would presume that a state government would embrace the short-term economic benefit and downplay environmental concerns. Indeed, states might actively compete with one another to provide the most comfortable terms possible for extracting industries. In contrast, under more recent analysis, the discovery of massive shale gas deposits would instead lead to far greater emphasis on assuring systematic environmental protection prior to any extended resource extraction. This might well entail use of a series of innovative environmental policy tools applied to the emerging case at hand, building on recent state experience in related areas.

This article begins to respond to these questions by offering an early exploration of the initial stages of state policy development for the extraction of 
"unconventional natural gas" in shale deposits through hydraulic fracturing (or "fracking") procedures. It devotes particular attention to a single case, the Commonwealth of Pennsylvania. This state has become a central player in the evolving national and international understanding of this issue given its vast shale deposits, exponential growth in resource development, and distinct visibility through massive media coverage and even popular documentaries and a major commercial film. It also has considerable prior experience with a number of the environmental policy tools reflected in the "race-to-the-top" model of state environmental governance. Pennsylvania alone cannot represent a full test of how multiple states might respond to the opportunities and challenges posed by massive shale discoveries. However, it is a very prominent first mover on this issue, having enacted the most far-reaching state legislation on this issue in the nation as of early 2013. This case can thus offer considerable insight into the early stages of state policy development in a context with such substantial federal statutory limitations at present that states have enormous latitude to chart largely their own course.

The article will demonstrate that Pennsylvania's approach to date, most notably the 2012 legislation enacted in Harrisburg, suggests that the state is emphasizing aggressive pursuit of short-term economic gains through resource development while demonstrating little rigor or innovation in pursuing environmental protection. This case suggests that a highly visible early mover in shale gas policy development is reinforcing an older approach to American environmental policy, perhaps launching a race to the bottom in the process. The article, however, will also consider factors that may not only constrain the implementation of this policy in Pennsylvania but also potentially limit its capacity to diffuse to other states as a model defining standard practice. Indeed, it is possible that this highly salient case could become an outlier of sorts rather than the norm as state policy development on shale gas accelerates around the nation, given both the early signs of a backlash in Pennsylvania and highly divergent policy options being considered in neighboring Marcellus Shale states as well as in those beyond the boundaries of that shale play.

\section{The Shale Gas Rush and the Question of Environmental Governance}

The existence of massive deposits of shale gas does not constitute a new discovery. A product of the mid-Devonian period of nearly four hundred million years ago, the abundant quantities of shale gas several miles below the earth's surface in a number of North American regions have long been known to geologists. However, the long-standing presumption was that it was simply not feasible technically or viable economically to extract the resource, despite the high demand for natural gas for electricity, heating, and possibly transportation as a far more environmentally friendly fossil fuel source than either coal or oil. Indeed, at the beginning of the current century, there was considerable lament in the United States that accessible natural gas supplies were on the decline and likely to be further eclipsed by more plentiful and less expensive coal.

The emergence of hydraulic fracturing technology involved less of a singular breakthrough and more of a general adaptation over several decades. The injection of massive quantities of water along with sand and chemical additives proved increasingly successful in recent decades in opening up rock formations and 
providing expanded access to gas and related energy sources. This technique was refined over time and linked in the early 2000s to growing capacity to establish horizontal extensions from vertical wells, thereby expanding markedly the capacity to access massive shale gas deposits. National shale gas yields grew twelvefold between 2000 and 2010, reaching one quarter of total natural gas production by 2011 and on track to reach approximately one half by 2035 (Energy Information Administration, 2011). The United States is not the only world source of shale gas or possessor of fracking technology, but it has quickly emerged as the dominant global source of gas generated from this source. At the same time, other nations are beginning to expand shale gas research and development while weighing a diverse set of emerging policy options of their own, potentially making early-mover cases such as Pennsylvania significant both domestically and internationally (Boersma \& Johnson, 2012).

\section{Pennsylvania Returns to Energy Center Stage}

At least 27 states have some amount of shale gas within their respective borders. No two states have identical deposits, and they generally have very diverse backgrounds in energy extraction, ranging from such established producers as Texas and Wyoming to such relative newcomers as Maryland and South Dakota. However, no American state has a longer or more prominent history with fossil fuel generation than Pennsylvania, reaching back to 1859 when Edwin Drake struck America's first oil well near Titusville. Pennsylvania quickly emerged as the top national—and global-source of oil, following an aggressive search around the state that has left a legacy of at least 180,000 drilled wells. That bounty rapidly began to decline, however. As early as 1885, the Pennsylvania state geologist warned that "the amazing exhibition of oil" was only a "temporary and vanishing phenomenon-one which young men will live to see come to its natural end." By the beginning of the twentieth century, the Russian Empire passed Pennsylvania as the largest global source of oil, and the state steadily declined in its production over subsequent decades (Yergin, 2011, p. 50). Coal underwent a somewhat parallel boom and bust, with a decline in mining linked to grim environmental consequences for Pennsylvania and neighboring states as well as to abundant low-sulfur coal sources elsewhere (Quigley, 2007; Tugwell, McElwaine, \& Kanche, 1999). Instead, Pennsylvania turned in more recent decades to policies that emphasized renewable energy and energy efficiency, also placing expanded emphasis on its state park system and historic sites amid potential expansion of its tourism industry.

Consequently, the realization that two thirds of Pennsylvania sat atop the Marcellus Shale, the estimated source of more than 50\% of the nation's total shale gas, opened questions of both potential economic gain and environmental considerations for the Keystone State. The Marcellus Shale "holds the largest untapped natural gas reserves in the nation" and "alone could provide enough natural gas to satisfy U.S. demand for at least a decade" (Pless, 2010, p. 1). Horizontal drilling began in Pennsylvania in 2003, one year after the technique debuted in Texas, and its first fracked natural gas was produced in 2005. This triggered a "shale gas rush" with some parallels to the 1860 s, leading to sudden and steady increases in the volume of natural gas being produced in Pennsylvania in recent years. A Penn State University 
study concluded that fracking had already added 21,000 direct jobs by 2009, with the likelihood of considerably more as development continued to expand (Considine, Watson, \& Blumsack, 2010). As legal scholar John Powell has noted, "If the Marcellus formation represents the most promising theatre of projected U.S gas production, Pennsylvania is perhaps its center stage" (Powell, unpublished data).

\section{Environmental Concerns}

The rapid onset of hydraulic fracturing for natural gas in many areas of Pennsylvania generated an array of potential environmental concerns. As in other states, fracking generally fell under well-established statutes and regulations governing traditional oil and gas drilling. However, in a number of instances, this new process represented far more than an incremental shift from conventional practice and hence markedly expanded the number of issues with potential environmental consequences. Fracking involves injection of a mixture of chemicals deep below the earth's surface, much of which returns to the surface over several months. This so-called "flowback" process can also entail release of such subterranean elements as "normally occurring radioactive materials" including radium and barium (Haluszczak, Rose, \& Kump, 2013). Numerous questions have emerged concerning the mixture of chemicals being injected and proper procedures for dealing with waste materials returning to the surface. In turn, one of the most common methods used nationally for disposal of these wastes, deep well injection, has become linked increasingly with earthquakes in such places as Arkansas, Ohio, Oklahoma, and the United Kingdom (Natural Research Council, 2012).

Fracking also entails questions of groundwater quality linked to drilling and well integrity and of water withdrawals due to the need to use up to seven million gallons of water for each fracking operation (Groat \& Grimshaw, 2012, pp. 42-43). Air quality concerns have also emerged in many contexts, given the release of air contaminants such as methane, which has considerably greater global warming potential per unit than carbon dioxide, as well as more conventional air emissions. Moreover, a range of land-use concerns have also surfaced, including on-site spills; chemical releases; and substantial traffic, noise, and disruption inherent in such massive drilling processes, particularly given the fact that they are frequently not confined to remote locations. As Richard Liroff of the Investor Environmental Health Network reported in 2012, "In the U.S., there have been numerous incidents of poorly constructed wells, equipment failures, degraded local and regional air quality, water contamination, strained community relations, and related government enforcement actions and private lawsuits" (Liroff, 2012, p. 3). These kinds of issues have surfaced increasingly in Pennsylvania in recent years, a reminder of earlier periods of environmental degradation linked to oil and coal development. Similar issues are also emerging in other states around the nation that are beginning to contend with fracking.

\section{Federal Limits}

The emergence of hydraulic fracturing as a major new natural gas source poses a range of environmental concerns that transcended a single environmental medium 
or the scope of an existing federal environmental program. However, even partial application of any federal law has been severely constrained by a set of exemptions and limitations. The Safe Drinking Water Act might have been a natural focal point for consideration of groundwater concerns, but 2005 amendments to the Energy Policy Act precluded it from reviewing any fracking-related chemical contamination except that which involved diesel fuel. Other established statutes such as the Resource Conservation and Recovery Act; Clean Water Act; and Comprehensive Environmental Responsibility, Compensation, and Reliability Act have long featured provisions or interpretations that restrict or preclude their application to oil and gas production operations. The Clean Air Act lacked statutory restrictions of this nature but has generally been applied only to large industrial point sources of air emissions, raising doubts concerning any potential transferability to a more decentralized air contamination threat such as proliferating well operations scattered across large sections of multiple states.

Any of these federal laws would only have addressed a limited component of overall environmental concerns regarding hydraulic fracturing. However, the constraints placed on their potential use further served to transfer lead authority for any emerging regulatory approaches to state governments as well as localities. Given the growing body of scholarly work that finds considerable evidence of subfederal environmental policy innovation, states such as Pennsylvania would appear to be tailor-made to take a constructive role in guiding fracking in environmentally sustainable ways. This might reflect growing state experimentation with programs that work across environmental medium lines (air, land, and water) and are designed to prevent contamination problems rather than respond to them after the fact (Rabe, 2002). Such state strategies might also employ some of the other policy tools that have been applied in a growing number of states, such as taxes and fees to mitigate potential environmental impacts and extensive public disclosure of chemical use and release to inform and facilitate constructive public engagement. Indeed, Pennsylvania has been fairly active in employing an array of these types of policy tools in energy and environmental policy domains during recent decades. Some of these very options were explored during the extended shale gas policy development process that Pennsylvania began in the late 2000s. Nonetheless, the Commonwealth chose to take a very different route through its 2012 legislation.

\section{Fracking Politics, Pennsylvania-Style}

Pennsylvania was not the first state to consider and then adopt legislation addressing the environmental ramifications of fracking. Many states focused on different dimensions of information disclosure and water quality provisions between 2007 and 2012 (Davis, 2012; Pless, 2012). Much of this work was somewhat piecemeal, in many cases modifying established drilling statutes and regulations to address the arrival of fracking. The enormous scale of Pennsylvania's shale gas resource would make any early policy that it established a barometer of whether states would race to the top via innovative policy or seek a more traditional strategy that was primarily designed to promote maximum resource extraction. Its decision to produce a detailed and far-reaching statute, driven by a convergence of political factors in 2011-12, only served to heighten the significance of its early-mover role. 
The rapid expansion of fracking operations throughout much of Pennsylvania after 2003 gave the issue substantial statewide visibility. Shale gas well development tends to be highly decentralized, thereby bringing a large number of sites and communities into direct contact with both economic development and environmental concerns. Responsibility for governing this growing and increasingly visible body of activity fell into the lap of the Bureau of Oil and Gas Management in the Pennsylvania Department of Environmental Protection (DEP). As is the case in many other states with prior experience in fossil fuel extraction, Pennsylvania had established statutes outlining permit and inspection requirements for conventional drilling in prior decades, long before the term "hydraulic fracturing" entered the energy lexicon. The bureau took the lead role in implementation of this earlier legislation. Ironically, the unit had generally been seen as in decline, given the decreasing forecasts for fossil fuel production in Pennsylvania. Much like its counterparts in many other states, the mission of the bureau had been somewhat suspect given its dual roles of promoting fossil fuel development while also implementing environmental protection provisions.

Political leaders at both the state and local levels quickly recognized as shale gas drilling proliferated that some modification of established governance practices would be likely, although there was no rapid emergence of consensus on what this would entail. Varied pieces of legislation were routinely introduced in every legislative session between 2003 and 2012; six bills and three nonbinding resolutions to Congress were approved between 2003 and 2008. Most of the legislation, however, was fairly narrow in scope, such as 2004 legislation that established the minimum distance between two wells. Resolutions generally implored Congress not to restrict fracking development in Pennsylvania through new legislation or regulations (Atherton \& Lehman, 2012).

More expansive proposals emerged but failed to reach consensus given partisan divides in Pennsylvania state government throughout this period. Governor Edward Rendell, a Democrat who served from 2003 to 2011, endorsed a wide range of energy legislation, including a renewable portfolio standard that was enacted in 2004 (Carley, 2011). He endorsed shale gas legislation that would, among other provisions, include a $5 \%$ severance tax on extracted fossil fuels. This tax would be comparable in structure to and close to the mean tax level in place in all of the 15 largest fossil fuel-producing states, with Pennsylvania the only such state without any such tax. However, Rendell was consistently unable to move fracking-related legislation forward, in part due to divided partisan control of the legislature throughout his tenure and diminished public standing during his last years in office. In response, Rendell supported some regulatory reform efforts within the Bureau and the DEP, primarily through adjustment of established statutes to emerging shale gas practices.

However, this more incremental process yielded to a decisive shift in Pennsylvania politics in 2010 that opened the door to a substantial legislative reform package that would be enacted into law in 2012. Enormous jumps in media coverage of the issue, both among in-state publications and major national newspapers and documentaries addressing Pennsylvania, reflected the soaring saliency of this issue. In turn, 2010 would generally prove a good election year for Republicans, and Pennsylvania was no exception. The party secured solid majorities in both the House 
(112 to 91) and the Senate (30 to 20), creating the possibility of a strong alliance with incoming Republican governor Tom Corbett, who had won a decisive victory with $54.5 \%$ of the total vote. This represented the first unified control by one party of all branches of state government in Pennsylvania since the arrival of massive shale gas developments.

Corbett was particularly outspoken during the 2010 campaign on prioritizing aggressive pursuit of shale gas and advancing legislation to minimize any potential governmental interference with intensive and rapid resource extraction. He had served multiple terms as attorney general, initially through a gubernatorial appointment in 1995 and subsequently via election in 2004 and reelection in 2008. Corbett was widely seen as closely aligned with the emerging shale gas industry, reflected in substantial campaign donations from these sources. Indeed, Corbett accepted more than $\$ 1$ million from the oil and gas industry for the 2010 campaign, his largest single source of campaign funding. He was adamantly opposed to any form of severance taxation for Pennsylvania, deriding this measure that had long been in place in Texas and all other major natural gas-producing states as "un-American."

Corbett sustained his focus on shale gas once in power, following a pattern in recent decades whereby governors can play a highly entrepreneurial role in energy and environmental policy development. In this case, he maintained a strong alliance with a large legislative majority from his own party and formidable oil and gas industry support. In his first official budget message as governor, he noted: "Let's make Pennsylvania the hub of this [drilling] boom. Just as the oil companies decided to headquarter in one of a dozen states with oil, let's make Pennsylvania the Texas of the natural gas boom. I'm determined that Pennsylvania not lose this moment. We have the chance to get it right the first time, the chance to grow our way out of hard days" (Bauers, 2011). Corbett remained highly visible and vocal in his support for continued shale gas development, most evident in his successful push for major legislation during 2012.

An electoral mandate and a pledge to promote shale gas development did not, however, automatically translate into a clear set of ideas for new legislation. Corbett had been adamant in the campaign concerning his opposition to severance taxes and desire for aggressive shale development. However, he had not been specific on how he would like to shape long-term policy for the state. Consequently, he formed a 30-member Marcellus Shale Advisory Commission via an executive order issued in March 2011. The commission was dominated by representatives of the oil and gas industry, including four members who lived outside of Pennsylvania, whereas environmental group representation was limited to a total of four members (Governor's Marcellus Shale Advisory Commission, 2011).

The commission produced a report within four months of its creation. It included nearly one hundred recommendations that addressed many dimensions of shale gas drilling, designed as a draft package of legislative amendments to the existing Pennsylvania Oil and Gas Act. Many of these recommendations were extremely detailed, such as the exact distance for setback requirements from private water wells and public water systems. The report was clearly intended to maximize near-term development of Pennsylvania's shale gas resources. It served as the foundation for the "Corbett Plan," the governor's formal legislative proposal, and 
many key facets of the governor's plan ultimately survived legislative review. In a vote that largely followed partisan lines, both chambers of the Pennsylvania legislature approved Act 13, known as the Unconventional Gas Well Impact Fee Act. Corbett signed the bill into law on February 14, 2012, stating that "thanks to this legislation, this natural resource will safely and fairly fuel our generating plants and heat our homes while creating jobs and powering our state's economic engine for generations to come" (Pittsburgh Post-Gazette, 2012).

\section{A Conventional Approach for an Unconventional Energy Source?}

The Pennsylvania Unconventional Gas Well Impact Fee Act covers 175 pages and is, in many respects, the most far-reaching single piece of state legislation passed to date on the issue of hydraulic fracturing and shale gas extraction. The legislation included a number of provisions never before enacted in any other state. It is extremely difficult to review the details of this legislation and view it as a model of state government commitment to environmental protection. Instead, it uses a combination of strategies to generally deter or constrain some of the features that are commonly associated with more recent periods of subfederal innovation. This includes very limited use of market-based and disclosure strategies, heavy reliance on state institutions known for their fealty to the energy industry, and aggressive state constraint on local government involvement. If anything, the legislation appears to represent a return to a much earlier period in American environmental governance when state involvement was far more deferential to industry preference.

\section{Constraining the Capture of Negative Externalities}

Every other major oil- and gas-producing state has long maintained some form of severance tax, which has routinely been applied as hydraulic fracturing practices have emerged and expanded. These are intended to capture some of the negative externalities imposed by the extraction process, often seen as monetary compensation for permanent resource loss. In turn, a number of states have applied at least some of these severance tax revenues toward costs related to state and local regulatory expenditures, environmental reclamation, and related economic development initiatives. Some states have seen these taxes emerge as major sources of total state government revenue, such as in Texas where a $7.5 \%$ energy severance tax produces approximately one tenth of total state revenues. The mean state tax rate is approximately $5 \%$ of gross value at the point of production. These types of taxes are also commonly used in other federal systems, such as Australia and Canada, where they are more commonly known as royalties.

Pennsylvania's Act 13 enabled the state to retain its distinct status as the only major producing state without such a tax, in part by reframing its cost-imposition strategy as an "unconventional gas well fee." This has become more commonly known as an "impact fee." In some respects, such a fee meets the legal definition of a tax, imposing a direct cost on some constituents. However, Pennsylvania crafted the fee to operate at a lower overall level than that of any other state and included a complex mechanism that shifted the actual political burden of fee adoption onto local governments. This enabled the state and its leaders to avoid political 
responsibility for imposing the fee. It also takes a large portion (40\% at minimum) of the local bounty for state government use and specifies local uses of any share that might be returned to these units (Act 13, Section 2315a.1). In addition, as we shall see, the fee has begun to be used as a state-level mechanism to deter any local government from taking environmental precautions beyond those set forth in the legislation, through the threat of withdrawing revenues in the event of local "noncompliance."

Any local effort to adopt an impact fee is confined to a 15-year period. If adopted by a local government, the fee could generate between $\$ 40,000$ and $\$ 60,000$ per well during its first year of operation, between $\$ 30,000$ and $\$ 55,000$ per well during its second year, and between $\$ 25,000$ and $\$ 50,000$ per well during its third year. During years four through ten, the fee would decline to an annual level between $\$ 10,000$ and $\$ 20,000$ per well and drop further to a level between $\$ 5,000$ and $\$ 10,000$ per year during years 11 through 15 . At that point, any additional impact fee payment would end, even in cases where the well is still active and productive. The actual level of the fee within these ranges would be dependent on a price averaging system for natural gas through a detailed formula specified in the legislation (Act 13, Section 2302b). This is thus fundamentally different from all other states with severance taxes, which place a fixed rate at the time of production over the entire life of the well, and then often supplement these taxes with additional well fees that subvent some related state and local government costs.

Preliminary estimates suggest that the fee would likely represent an effective tax rate of approximately $2 \%$ during the initial years of fee operation but that this would decline markedly in later years. This remains substantially below the effective tax rate of all other state oil and gas producers, as noted above, and is unique in its concentration of revenue generation in the initial years of well operation. This is particularly well suited for a political cycle that provides near-immediate fiscal benefits to the very governor and legislature that establish the fee and then fades away in later years once successors likely take office. Indeed, the final year that Corbett could serve as governor, assuming reelection in 2014, would be 2019 due to term limitations. The average legislative tenure for current members of the Pennsylvania House is just over ten years in length, suggesting that a large percentage of legislators who passed this legislation will be out of office as revenues from the wave of wells being permitted in the late 2000s and early 2010s dry up at the end of the decade.

No participating locality may adjust the fee rate or the usage of any funds that it might receive from the state's fee collection process. Indeed, the legislation makes clear that the state retains full authority over both of these features, maintaining control over most key elements of the process while forcing local governments to actually take the political step to impose the fee within their boundaries. The revenue that remains after the state takes its share is then divided between participating county and municipal governments.

\section{Constraining Local Government Engagement}

Act 13 enables the ability of the state to withhold impact fee revenue from any local government that establishes an ordinance deemed inconsistent with the detailed 
state land-use provisions set forth in the legislation. This constitutes an extremely unusual linkage of state fiscal and regulatory power in attempting to constrain local policy latitude. Local governments electing to establish an impact fee in Pennsylvania immediately began to discover that this can provide state officials with a powerful tool to constrain local authority to shape a wide range of decisions linked to the approval and oversight of shale gas operations. State authorities withheld revenues from seven Pennsylvania municipalities during 2012.

Alongside the cudgel of revenue withdrawal, Act 13 also takes far-reaching steps to remove traditional land-use authority from local governments. These are designed to remove localities as potential impediments to aggressive resource development. Ironically, Pennsylvania has historically delegated substantial authority for land-use decisions to local governments under its Municipal Planning Code (P.L. 805, no. 247). The Code requires all local zoning ordinances to allow for the "reasonable development of minerals," expressly including oil and gas. However, Section 602 of the Code gives local governments substantial latitude to define "reasonable development" and make fundamental decisions concerning the wide range of zoning and land-use approval considerations linked to opening well operations, providing transportation access, and securing basic safety and publichealth protections at or near any site. The application of these extensive provisions to shale gas was generally supported by a 2009 Pennsylvania Supreme Court decision. In this case, the state court did impose some constraints on local oversight of the "technical aspects" of well construction but generally upheld the idea of far-reaching local authority.

The new legislation strips away much of this local role through the creation of very detailed provisions for most key areas of well siting and operations, such as setback distances from other buildings, property lines, or water bodies. These provisions have generally been enthusiastically received by shale gas developers, as they establish uniform standards throughout the state and largely eliminate the possibility of local government efforts to challenge or modify them. In fact, the legislation expressly prohibits a wide range of possible areas of local engagement that have historically been addressed in Pennsylvania under local zoning codes. These include prohibitions against local government attempts to restrict well site operating hours, conditions for screening and fencing around the site, or limiting structural height or noise from facility operations.

Section 3304 of the legislation is particularly detailed in what it removes from potential review and engagement by local governments, even in cases where well operations were located in heavily populated areas in close proximity to other residential and commercial activity. This includes strong constraints on local capacity to address seismic operations, pipeline installation and repair, well development and operation, and transportation routes for bringing employees and equipment to any drilling site. The legislation further prohibits localities from imposing any constraints on shale gas operations "that are more stringent than conditions, requirements or limitations imposed on construction activities for other industrial uses within the geographic boundaries of the local government" (Section 3304b). This provides state authorities with additional latitude to further restrict local activity beyond those extensive provisions specified in the legislation by treating hydraulic fracturing no differently from other industrial activities. 
State authorities, however, also retain two other mechanisms to reduce the likelihood of any significant local encroachment on these new provisions and thereby accelerate shale gas development. First, the state can not only withdraw impact fee funds from a particular locality but can declare it "immediately ineligible to receive any funds" in the event that the state finds that any local land-use decisions have encroached on its newly established terrain. This serves to bypass any state and local negotiation over the legality of local provisions through an immediate imposition of a financial penalty, one likely to be most significant in the early stages of development given the front-loaded nature of the impact fee, as discussed previously. Second, the new legislation further constrains local government authority by expressly prohibiting any municipal right to challenge state regulatory decisions related to shale gas well permits. Under the new statute, "no municipality or storage operator shall have a right of appeal or other form of review" from a state agency decision. It allows local officials to "comment" on any pending permit cases but does not obligate the state to consider those comments, much less respond to them.

Collectively, these steps represent a significant centralization of authority under state auspices, largely eviscerating the possibility of constructive engagement between state and local governments in Pennsylvania. It places remarkable specificity in defining the boundaries of proper conduct related to shale gas development in a new piece of state legislation and does so in ways generally designed to maximize rapid extraction of the available energy source. The legislation runs counter to the policy approaches taken by many states in recent decades, as it removes from possible use many of the policy tools that local governments might consider using in advancing environmental protection considerations as shale gas drilling proposals expand.

\section{Constraining State Agency Innovation}

The Pennsylvania Unconventional Gas Well Impact Fee Act also goes some distance to avoid any significant restructuring of state government departments or commissions with a role in shale gas development. Substantial innovation in state environmental policy, including work to reduce cross-media transfers and emphasize preventive strategies, has emerged through intra-agency innovation and cross-unit collaboration. Pennsylvania is one of many states with considerable prior engagement in this area (Rabe, 2002). Some states have begun to apply this experience to shale gas. For example, Colorado has completed "an organizational shake-up" of its Oil and Gas Conservation Commission. This has included broadened and diversified commission membership of "an organization previously dominated by individuals with an industry background" (Davis, 2012, p. 187). One important component of this restructuring is the inclusion for the first time of the heads of the Departments of Natural Resources and Public Health and Environmental Protection as commission members. In contrast, Pennsylvania's new legislation does not take comparable steps. Instead, Act 13 has created a unique governance structure that is seemingly designed to minimize any threats to rapid resource development.

The 2012 legislation made Pennsylvania the first state to give its public utility commission as the a lead role in implementing key provisions of shale gas 
policy. Such commissions were established in many states in the early twentieth century to oversee electricity generation and distribution, with Pennsylvania creating its unit in 1922 (Gormley, 1983). The Pennsylvania Public Utility Commission (PUC) has retained traditional functions such as approval of major generating facilities and oversight of rate-setting practices, but it had never before been seen as an environmental regulatory body or an entity for collecting energy tax revenues. Nonetheless, it emerged as the state's choice to take the lead role in overseeing local impact fee implementation as well as related regulatory provisions. This includes designation of whether counties are eligible for participation in this program. However, it also entails the authority to determine whether local governments have violated some aspects of the new state legislation and are rendered ineligible to receive their share of impact fee revenues, even though it may continue to be assessed within their boundaries and collected by the state. Thus, this important component of the Pennsylvania shale gas strategy was unexpectedly deposited in the hands of a body whose commissioners are gubernatorial appointees and that has never played a major role in environmental protection law enforcement. The legislation created no linkage between the PUC and other prominent agencies with expertise in these areas, and the commission quickly created a request for proposals from law firms that might assist it with interpretation.

Act 13 also served to constrain the role of the DEP and its Bureau of Oil and Gas Management in issuance of any permits related to shale gas development. The considerable specificity in the statute restricted agency capacity for interpretation and innovation. Moreover, the legislation specifies that the DEP must issue permits within 45 days from the point of application unless it denies a proposal for one of six specific reasons. It may seek one 15-day extension if it can demonstrate "cause," but is otherwise under considerable time pressure to conduct a case review and reach a final decision. Pennsylvania has experimented previously with some accelerated environmental permit decisions, though these were expressly linked to efforts to assure better integration across multiple program boundaries. The new legislation thus puts unusually tight time limitations on such permits, thus allowing very limited opportunity for environmental review or consideration of factors distinct to each individual well operation.

\section{Constraining Public Access to Information and Public Input}

One of the most contentious aspects of shale gas development has been the issue of disclosing to state agencies and the general citizenry information concerning the mixture of chemical substances being injected into wells or returning to the surface through the "flowback" process. Precedents such as the chemical disclosure provisions in federal right-to-know policies and expanded state counterpart programs have been considered in many states, although these generally provide significant exemptions for releases from the oil and gas industry and so do not necessarily apply to shale gas (Kraft, Stephan, \& Abel, 2011). Indeed, a major focal point in a number of early state legislative reviews of shale gas development has been the question of disclosure given the absence of federal direction. Such reviews invariably weigh the competing concerns of transparency aimed at environmental and public health protection versus protecting the interests of resource development 
firms. Disclosure also figured prominently throughout the Pennsylvania deliberations and some early legislative proposals, prior to completion of detailed disclosure provisions in Act 13 .

Pennsylvania's 2012 legislation leans decisively toward protection of industry interests in response to concerns that release of chemical use information could violate confidential trade secrets. Act 13 establishes very few mandatory disclosure requirements and specifies that drilling well operators "may designate specific portions of the stimulation record as containing a trade secret or confidential proprietary information" (Section 3222b2). It does allow for a "health professional" to secure some access to chemical use information in the event of a "medical emergency." However, this must include "a verbal acknowledgement by the health professional that the information may not be used for purposes other than the health needs asserted and that the health professional shall maintain the information as confidential" (Section 3222.1). There is no discussion in the legislation of other possible venues to expand public access barring some form of medical emergency that was presumably linked to a public health disaster. In some respects, the most important disclosure activity emerging to date in Pennsylvania involves posting of select information on a Web site via the FracFocus Chemical Disclosure Registry, which is operated by the Interstate Oil and Gas Compact Commission and Ground Water Protection Council. This reporting is voluntary, and the FracFocus process has been widely criticized as providing only limited information while using a format that makes comparative case scrutiny extremely difficult.

Pennsylvania's restricted definition of disclosure is further demonstrated in formal limitations on the applicability of other statutes designed to promote transparency to agencies involved in shale gas regulation. Some elements of this strategy move beyond constraining public access to information and instead place firm limits on provisions for public input. In particular, the PUC is expressly exempted from provisions of the Pennsylvania Sunshine Act and related statutes that are intended to assure public accountability in the actions of state administrative agencies. This exemption includes any PUC decisions that would involve impact fee oversight and reversal of local ability to receive fee revenues if found in violation of some provision of Act 13. Moreover, the rapid timetable for DEP permit decisions does not include any provisions for assuring some form of public input into this accelerated review, and the strict limitations on local interpretation of state zoning codes significantly constrains the possibility of local awareness of and involvement in those decisions.

\section{Second Thoughts and Potential Limits on Policy Resiliency}

Pennsylvania's enactment of the Unconventional Gas Well Impact Fee Act raises a number of questions concerning the ability of state governments to respond to the emergence of massive shale gas deposits with the kind of creative policy that blends environmental protection with economic development considerations. Act 13 clearly contrasts with many of the innovative modes of environmental governance that have been highlighted in an expanding literature on state environmental policy. As one of the likely dominant states in shale gas development and one of the first to adopt such a far-reaching policy, Pennsylvania's "early-mover" actions could loom large. Its legislation might emerge as a model of sorts that sets a standard for 
subsequent policy developments in other states in the continued absence of guiding federal policy. Just as some states such as California are widely seen as early movers and thereby trendsetters through a penchant for early action as environmental issues emerge, the Pennsylvania case might set a significant precedent and provide a policy model in cases where states opt for rapid and aggressive resource development for short-term economic development while downplaying environmental protection.

However, it was not immediately evident that the 2012 Pennsylvania legislation would prove resilient, much less influence policy outside state boundaries. Indeed, a series of political and legal controversies surfaced within the state during initial stages of implementation, and public opinion research demonstrated that citizen opinions differed considerably from those of the elected officials responsible for Act 13 on such issues as chemical disclosure and establishment of severance taxes. In turn, some cross-border concerns also began to emerge as states neighboring Pennsylvania began to claim that they were being adversely affected by shale gas practices from their neighbor. Finally, there is no immediate evidence to suggest that Pennsylvania had "set the standard" for shale gas policy, based on continued policy development processes in a large number of other states. Thus, the Pennsylvania legislation remains highly significant, but both its durability and capacity for early-mover influence proved uncertain during its first year of implementation.

\section{Local Resistance and Court Involvement}

Shale gas drilling was underway in more than half of Pennsylvania's 67 counties at the time of Act 13 enactment, including many legislative districts with members who had voted in favor of the legislation. Consequently, early stages of implementation of the new state legislation had immediate impact, including local decisions on impact fee adoption and the recognition that a wide range of emerging local ordinances were likely invalid given state preemption of local authority. This triggered considerable local backlash, resulting in numerous legislative reform proposals and a yearlong battle in the state court system over the constitutionality of local constraint provisions.

The question of eclipsed local control had emerged as one of the most contentious issues with the final legislative package and left its approval in some doubt. Just two weeks before the final passage, nine Republican senators wrote Governor Corbett to "express our opposition to language that removes a local municipality's ability to regulate and control all land use in their area." They noted that the legislation "actually works more like a model ordinance by specifically spelling out permitting uses." Corbett responded within days and essentially dismissed the concerns; he noted emerging local oil and gas ordinances that would generate inconsistencies across the state and likely deter full resource development. The Governor's letter emphasized that "[a]s you know well, Pennsylvania is currently engaged in efforts to attract significant outside capital investment to develop those resources-investment which means thousands of well-paying jobs and plentiful and affordable feedstock for our plastics and chemical manufacturers. We cannot afford to lose these opportunities." The legislative majorities held in both chambers, although the margins were close and reflected tight partisan divides. 
Intergovernmental tensions flared in 2012 as many counties and municipalities began to come to terms with their newly constrained role with existing or proposed shale gas operations. This generated expanding pressure on state senators and representatives, particularly Republican legislators who endorsed the legislation in February 2012, to introduce amendments to Act 13 that would allow special treatment for their respective districts. Implementation of both the impact fee and local preemption provisions of the Pennsylvania legislation also triggered conflict, including in legislative districts with Republican representatives who had supported the legislation but began to express doubt. In turn, Democrats repeatedly flooded the legislature in 2012 with various amendments that would make marked changes in Act 13. House Democrats, for example, introduced their "Marcellus Compact," a suite of six bills that would lead to substantial revisions of Act 13. House Minority Leader Frank Dermody noted that "the Marcellus Compact is our attempt to right the wrongs of Governor Corbett's sham of a Marcellus Shale law" (Pennsylvania House Democratic Caucus, 2012). A more fundamental challenge to the legislation took shape as local governments sought to overturn key provisions of Act 13 through the state court system, although final resolution of this case was pending in early 2013 .

\section{Public Opposition}

Pennsylvania may not only be a forerunner in enacting far-reaching state shale gas legislation but may also be one of the first states with high levels of public opposition to its policy approach. A series of statewide public opinion surveys conducted in 2011 and 2012 by the National Surveys on Energy and Environment (NSEE) found considerable public support in Pennsylvania for continued pursuit of shale gas via hydraulic fracturing but registered a number of concerns regarding possible environmental threats. This analysis also found considerable support for extensive public disclosure, some form of severance tax, and continued local input on landuse decisions, all contrary to core elements of Act 13 (Brown, Hartman, Borick, Rabe, \& Ivacko, 2013).

A fall 2012 NSEE survey found that $91 \%$ of survey participants supported required disclosure of chemicals injected underground for drilling purposes, with $87 \%$ rejecting the proposition that disclosure should be restricted to allow drilling firms to protect trade secrets. Pennsylvanians also demonstrated strong support for creation of a severance tax, with $65 \%$ of fall 2012 respondents supportive of such a proposal, $27 \%$ in opposition, and $8 \%$ unsure. Both of these findings were consistent with all previous recorded surveys on this issue in Pennsylvania. In turn, there is no evidence of strong public support for a state-dominated regulatory process, and there is substantial public concern regarding water quality and related environmental protection risks.

Neither the survey work conducted before the Unconventional Gas Well Impact Fee Act nor that conducted after it suggests anything approaching majority support for some of its key provisions on disclosure, taxation, and intergovernmental roles in regulation, among others. In turn, the public continues to see the area of shale gas development as one with considerable promise but also posing risks, while consistently raising questions concerning the efficacy of Governor Corbett's stewardship on this issue and his close ties to the gas industry. All of this suggests a 
rather wobbly base of public support for major new legislation that has had unusually high saliency in recent years. Public opposition intensified throughout the state in 2011 and 2012, involving established environmental protection groups and new entities guided by so-called "fracktivists" in formal protests. Act 13 immediately came under scrutiny in the early stages of preparation for the 2014 electoral campaign, including a 2012 announcement by a former DEP head that he would seek the Democratic gubernatorial nomination on a platform emphasizing farreaching shale gas policy reforms and increased development of renewable energy sources and enhancement of energy efficiency within the state (Micek, 2012).

\section{Cross-Border Tensions}

Pennsylvania's governance approach to fracking has also raised the hackles of neighboring states, all of which are in varied stages of developing their own policies on the issue. Most notably, considerable tension has arisen between Ohio and Pennsylvania over the issue of managing flowback wastes that return to the surface after fracking operations. This began to emerge as a major concern in Pennsylvania in 2010 and 2011, in the run-up to enacting Act 13, but has only intensified since that time.

One common method for handling these wastes is reinjection into deep wells. However, Pennsylvania geological conditions rule out the use of all but a handful of wells for this task, leaving only seven possible wells in the state available for injection in 2012. This limited available in-state options, leading to an increasing tendency for drill site operators to ship flowback wastes to publicly owned wastewater treatment facilities. However, this raised many safety and public health concerns, particularly given the limited information concerning the mixture of chemicals in the flowback wastes. In 2011, Governor Corbett and the Pennsylvania DEP requested that operators voluntarily halt disposal of these wastes through wastewater treatment facilities. In turn, they responded with a dramatic increase in the volumes of waste exported, most frequently to Ohio, which had nearly 200 potential injection well sites. Many of these were located near the Ohio-Pennsylvania border.

This not only opened the traditional concern regarding cross-border transfer of wastes but reached heightened saliency as eastern Ohio began to experience a significant increase in the frequency and intensity of earthquakes ranging in Richter scale magnitude from 2.7 to 4.0 in recent years. Many of these have been concentrated in the Youngstown area, in close proximity to major flowback waste injection, with analyses from the U.S. Geological Service and the Ohio Department of Natural Resources confirming a linkage (DiCosmo, 2012). Local government officials in Ohio were quick to condemn Pennsylvania's unwelcome waste exports. As one Hubbard Township official noted, "It's too toxic to discharge into the ground in Pennsylvania, but it's OK to discharge into the ground in Ohio" (Gilbert, 2012).

Cross-state contamination concerns have also surfaced on the southern border of Pennsylvania, with Maryland's attorney general threatening litigation after a May 2011 "blowout" of a shale gas well released several thousand gallons of contaminated fluid into a creek that flowed in Maryland. Still further concern has arisen in Maryland over a possible increase of air emissions arriving there from expanded fracking operations in Pennsylvania, potentially exacerbating air quality problems 
in neighboring Northeastern states with long-standing complaints over being on the receiving end of Pennsylvania-based air emissions.

The new Pennsylvania legislation does not specifically address any of these issues. However, the legislation is widely perceived as upholding Pennsylvania's reputation for all-out pursuit of its shale gas resources, even to the detriment of neighboring states. These out-of-state concerns address environmental considerations but also underscore possible problems that Pennsylvania's approach might have for its own efforts to develop internal shale gas resources. For example, the Ohio Oil and Gas Association supported underground waste injection as the safest disposal method but openly lamented that the surge of unwanted waste imports from Pennsylvania may serve to restrain disposal options for expanding Ohio operators and also increase their costs. These conflicts raise questions concerning whether Act 13 will be viewed as a model worthy of emulation or perhaps instead become a target of opposition from cross-border neighbors who find themselves on the receiving end of negative externalities

\section{Follow the Early Mover or Other Policy Paths?}

Enactment of far-reaching legislation by a major state player in the development of an energy resource inevitably generates the question of whether or not that step will influence policy development in other states and regions. Indeed, American politics has long featured subnational policy diffusion patterns, with energy and environmental protection no exception (Posner, 2010; Rabe, 2011). The actions of state early movers have long influenced other states and even later federal policy. Pennsylvania's enactment of Act 13 raised the possibility that it might constitute a rejection of more recent state environmental and energy policy development that emphasized rigorous and innovative policy design in favor of an all-out pursuit of aggressive resource development that minimized environmental concerns. This could indicate that massive anticipated economic gains from new energy development opportunities could serve to push environmental considerations to the margins of policy. However, there is no immediate evidence to suggest that Pennsylvania will trigger a body of comparable adoption elsewhere, whether among immediate neighbors where political leaders have expressed strong interest in tapping into their own share of the Marcellus Shale or in other states atop shale plays around the nation. Hence, the potential impact of this early-mover state is very much in question, just as the long-term resiliency of Act 13 may be uncertain.

A diverse array of state policy options began to emerge as Act 13 approached its first anniversary since passage. Many states continued to explore incremental adjustment of established policies, often emphasizing disclosure or another singular component as opposed to far-reaching reforms. Others began to consider some form of moratorium on fracking, at least until completion of full review by designated state agencies. New York entered the fourth year of its moratorium and review in 2013, which included exploration of ways to best utilize its environmental impact assessment process for multifaceted shale gas drilling operations. One possible outcome would allow fracking to take place in a number of economically distressed counties along the Pennsylvania border, pending local assent through some form of ballot proposition. Still additional options began to emerge in other 
states, including the growing possibility that California might enact far-reaching legislation that would place strong emphasis on environmental protection and extensive disclosure provisions. Of course, all of this statehouse activity moved forward amid some federal agency exploration of expanding their authority over some elements of fracking in the absence of any sign of new federal legislation.

The disparate experience of these respective states suggests that policy formation related to shale gas extraction remains very much in early stages of review in American states that rest atop shale plays. Pennsylvania has thus taken a major early policy step, one in sharp contrast with the common theme in the literature on subfederal policy that emphasizes innovation and commitment to environmental protection as core tenets. However, it is not at all evident that Pennsylvania represents a model that will serve to guide diffusion in other jurisdictions as they begin to formulate their own responses to the opportunities and challenges of shale gas. In short, shale play policy remains very much in play in state capitols that may need to address this issue given their geological inheritance.

\section{Acknowledgments}

The authors are very grateful to three anonymous reviewers for insightful comments on an earlier version of this paper. They received extremely helpful comments from Roxanne Balmas, Elizabeth Bomberg, Christopher Gore, Erick Lachapelle, Richard Liroff, Scott Miller, Jacquelyn Pless, Andrew Rabe, Matthew Rabe, Erich Schwartzel, and participants in a panel discussion at the 2012 Annual Meeting of the Canadian Political Science Association in Calgary where the paper was presented.

\section{About the Authors}

Barry G. Rabe is the J. Ira and Nicki Harris Family Professor of Public Policy at the Gerald R. Ford School of Public Policy at the University of Michigan, Ann Arbor, Michigan, USA, where he is also an Arthur F. Thurnau Professor. Rabe is the Director of the Ford School's Center for Local, State, and Urban Policy and also holds appointments in the Department of Political Science, the Program in the Environment, and the School of Natural Resources \& Environment. He is a non-resident senior fellow in the Governance Studies Program of the Brookings Institution. In early 2013, he was named to the National Research Council committee on Risk Management and Governance Issues in Shale Gas Extraction. Rabe's most recent book is Greenhouse Governance: Addressing Climate Change in America, edited and published in 2010.

Christopher Borick is a Professor of Political Science at Muhlenberg College and Director of the Muhlenberg College Institute of Public Opinion in Allentown, Pennsylvania, USA. His areas of expertise include environmental and energy policy and public opinion research. He is co-director of the National Surveys on Energy and the Environment (NSEE) and the President of the Pennsylvania Political Science Association.

\section{References}

Atherton, M., \& Lehman, D. (2012, March). Gas boom: Agenda-setting and the Marcellus Shale in Pennsylvania. Paper presented at the Annual Meeting of the Pennsylvania Political Science Association.

Bauers, S. (2011, March 29). Corbett cheers natural gas drilling. The Philadelphia Inquirer.

Boersma, T., \& Johnson, C. (2012). The shale gas revolution: U.S. and EU policy and research agendas. Review of Policy Research, 29, 570-576. 
Brown, E., Hartman, K., Borick, C., Rabe, B., \& Ivacko, T. (2013). Public opinion on fracking: Perspectives from Michigan and Pennsylvania. Ann Arbor, MI: Center for Local, State, and Urban Policy, Gerald R. Ford School of Public Policy, University of Michigan.

Carley, S. (2011). The era of state energy policy innovation: A review of policy instruments. Review of Policy Research, 28, 265-294.

Considine, T., Watson, R., \& Blumsack, S. (2010). The economic impacts of the Pennsylvania Marcellus Shale natural gas play: An update. University Park, PA: Pennsylvania State University, Department of Energy and Mineral Engineering.

Craik, N., VanNijnatten, D., \& Studer, I. (2013). Designing integration: Regional governance on climate change policy in North America. Toronto: University of Toronto Press.

Davis, C. (2012). The politics of "fracking": Regulating natural gas drilling practices in Colorado and Texas. Review of Policy Research, 29, 177-191.

Dernbach, J. (2012). Acting as if tomorrow matters: Accelerating the transition to sustainability. Washington, DC: Environmental Law Institute.

DiCosmo, B. (2012, March 21). New study could help EPA address growing seismic risks from fracking. Clean Energy Report.

Energy Information Administration. (2011). International Energy Outlook 2011. Washington, DC: Energy Information Administration.

Fiorino, D. J. (2006). The new environmental regulation. Cambridge, MA: MIT Press.

Gilbert, D. (2012, January 3). Ohio shuts wells following quakes. Wall Street Journal.

Gormley, W. (1983). The politics of public utility regulation. Pittsburgh, PA: University of Pittsburgh Press.

Governor's Marcellus Shale Advisory Commission. (2011). Governor's Marcellus Shale Advisory Commission Report. Harrisburg, PA: Pennsylvania Department of Environmental Protection.

Groat, C. G., \& Grimshaw, T. W. (2012). Fact-based regulation for environmental protection in shale gas development. Austin: Energy Institute at the University of Texas.

Haluszczak, L. O., Rose, A. W., \& Kump, L. R. (2013). Geochemical evaluation of flowback brine from Marcellus gas wells in Pennsylvania, USA. Applied Geochemistry, 28, 55-61.

Kraft, M. E., Stephan, M., \& Abel, T. W. (2011). Coming clean: Information disclosure and environmental performance. Cambridge, MA: MIT Press.

Liroff, R. A. (2012). Extracting the facts: An investor guide to disclosing risks from hydraulic fracturing operations. Washington, DC: Investor Environmental Health Network.

Mazmanian, D. A., \& Kraft, M. E. (Eds.). (2009).Toward sustainable communities: Transition and transformations in environmental policy, revised edn. Cambridge, MA: MIT Press.

Micek, J. (2012, November 28). Ex-DEP secretary John Hanger to run for Pennsylvania governor. The Morning Call.

National Research Council. (2012). Induced seismicity potential in energy technologies. Washington, DC: The National Academies Press.

Pennsylvania House Democratic Caucus. (2012, May 25). House Democrats introduce "Marcellus Compact" to fix flawed shale drilling law. Retrieved from: www.pahouse.com/PR033052512.asp

Peterson, P. E. (1995). The price of federalism. Washington, DC: Brookings Institution Press.

Pittsburgh Post-Gazette. (2012, February 14). Corbett signs shale gas impact fee into law.

Pless, J. (2010). Regulating hydraulic fracturing: States take action. Denver, CO: National Conference of State Legislatures.

Pless, J. (2012). Natural gas development and hydraulic fracturing. Denver, CO: National Conference of State Legislatures.

Posner, P. L. (2010). The politics of vertical diffusion: The states and climate change. In B. G. Rabe (Ed.), Greenhouse governance: Addressing climate change in America (pp. 73-100). Washington, DC: Brookings Institution Press.

Quigley, J. (2007). The day the earth caved in: An American mining tragedy. New York: Random House.

Rabe, B. (2011). Contested federalism and American climate policy. Publius: The Journal of Federalism, 41(3), 494-521.

Rabe, B. G. (2002). Permitting, prevention, and integration: Lessons from the states. In D. F. Kettl (Ed.), Environmental governance (pp. 14-57). Washington, DC: Brookings Institution Press.

Rabe, B. G. (2013). Racing to the top, the bottom, or the middle of the pack? The evolving state government role in environmental protection. In N. Vig \& M. Kraft (Eds.), Environmental policy: New directions for the 21st century (pp. 30-53). Washington, DC: Sage/CQ Press.

Selin, H., \& VanDeveer, S. (Eds.). (2009). Changing climate in North American politics. Cambridge, MA: MIT Press.

Tugwell, F., McElwaine, A. S., \& Kanche, M. (1999). The challenge of the environmental city: A Pittsburgh case study. In D. A. Mazmanian \& M. E. Kraft (Eds.), Toward sustainable communities (pp. 187-216). Cambridge, MA: MIT Press.

Yergin, D. (2011). The quest: Energy, security, and the remaking of the modern world. New York: Penguin. 